\title{
Morphology and molecular phylogeny of prorocentrum consutum sp. nov. (dinophyceae), a new benthic dinoflagellate from south Brittany (northwestern France)
}

\author{
Nicolas Chomérat ${ }^{1,{ }^{*}}$, Daniel Y. Sellos ${ }^{2}$, Frédéric Zentz ${ }^{3}$, Elisabeth Nézan ${ }^{1}$ \\ ${ }^{1}$ IFREMER, Laboratoire Environnement et Ressources Finistère-Bretagne Nord, 13 rue de Kérose, 29187 \\ Concarneau Cedex, France \\ ${ }^{2}$ Muséum National d'Histoire Naturelle, Station de Biologie Marine, B.P. 225, 29182 Concarneau Cedex, France \\ ${ }^{3}$ Université de Bretagne Occidentale - Institut Universitaire de Technologie, 2 rue de l'Université, 29334 Quimper \\ Cedex, France
}

*: Corresponding author : Chomérat N., email address : $\underline{\text { nicolas.chomerat@ifremer.fr }}$

\begin{abstract}
:
A new marine benthic Prorocentrum species from sandy habitats of South Brittany (northwestern France), P. consutum sp. nov., is described using LM and SEM and molecular phylogenetic analyses. Cells have a subcircular to broadly ovoid shape and are plainly flattened. They are 57-61 $\mu \mathrm{m}$ long and $52-55 \mu \mathrm{m}$ wide. A central pyrenoid is present, and the kidney-shaped nucleus is positioned in the posterior region. In right valve view, the periflagellar area is deeply excavated, and the left valve forms a prominent apical ridge. The periflagellar area consists of nine platelets, and a small narrow collar is present around the flagellar pore. The ornamentation of this new species is very peculiar and is characterized by a ring of round areolae located at the periphery of the valves, each areola containing three or four pores. Apart from this ring of areolae, the cell surface is smooth and with scattered pores. Pores are not present in the center of the right or left valve. The intercalary band is generally narrow and faintly striated horizontally. The molecular phylogenetic position of $\mathrm{P}$. consutum sp. nov. was inferred using SSU and LSU rDNA. In both analyses, this species branched with high support in the clade comprising species with a symmetric shape and appeared to be a sister group to that formed by P. lima and other tropical benthic species, such as P. arenarium, P. belizeanum, P. hoffmannianum, and P. maculosum.
\end{abstract}

Keywords: dinoflagellates $\bullet$ LSU rDNA • molecular phylogeny • nuclear DNA • Prorocentrum • SEM • SSU rDNA • taxonomy 


\section{Introduction}

The genus Prorocentrum was erected by Ehrenberg in 1834, with $P$. micans as the type species. It comprises several species common in the plankton of the world's ocean and also benthic or sand-dwelling species that live in the sand or on macroalgae.

Originally, most benthic species were described in the genus Exuviaella Cienkowski, which lacks an apical spine or tooth and therefore, was distinct from Prorocentrum. The possible synonymy of the two genera was expressed by Abé (1967) and has long been discussed (Loeblich 1970, Dodge 1975, McLachlan et al. 1997). In a revision of the genus Prorocentrum, Dodge (1975) formally made Exuviaella a junior synonym of Prorocentrum on the basis of ultrastructure studies and the number of chromosomes. This proposition has been widely accepted, but McLachlan et al. (1997) presented arguments to reinstate Exuviaella for benthic, large, and often toxic species lacking an apical spine or tooth. However, these arguments have not been widely accepted although some new molecular data showed that two distinct clades early diverged in the phylogeny of the genus Prorocentrum (Grzebyk et al. 1998, Murray et al. 2007, Faust et al. 2008).

During the last two decades, the number of described benthic Prorocentrum species has considerably increased, in particular in the tropical area where M.A. Faust discovered and described several new species in coral-reefs mangroves and lagoons of Belize (Faust 1991, 1993a, 1993b, 1994, 1997, Faust et al. 2008). In temperate, coldwater environments, the number of species seems relatively low but these areas have been comparatively little sampled (Dragesco 1965, Larsen 1985, Hoppenrath 2000a, b).

In France, the diversity of benthic dinoflagellates has been studied in north Brittany where several new taxa were described (Balech 1956, Dragesco 1965) and we 
first investigated samples from two locations of South Brittany in 2003. Owing to the interesting diversity discovered, sampling has been carried out recurrently each summer. In recent papers, we described new sand-dwelling taxa in the genera Sinophysis and Cabra from these places (Chomérat et al. 2009, Chomérat and Nézan 2009). The present paper provides a detailed morphological study of a new benthic Prorocentrum species, $P$. consutum sp. nov., first discovered in sandy sediments in 2003 , and then occasionally observed. In addition, a molecular characterization of this new species has been realized in order to analyze its phylogenetic position among other Prorocentrum species.

\section{Materials and Methods}

Samples collection

Sampling was performed at two sites located in South Brittany. Samples were collected at a site east of Moutons Island $\left(47^{\circ} 46^{\prime} 00^{\prime \prime} \mathrm{N}, 4^{\circ} 00^{\prime} 00^{\prime \prime} \mathrm{W}\right)$ in the Glénan Archipelago and at another site east of Groix Island $\left(47^{\circ} 38^{\prime} 00^{\prime \prime} \mathrm{N}, 3^{\circ} 27^{\prime} 44^{\prime \prime} \mathrm{W}\right)$ (Chomérat et al. 2009). Sampling was carried out by SCUBA diving between 5 and $13 \mathrm{~m}$ water depth (at mid-tide) between June and September since 2003. Each sample was collected by scraping the top 3-5 mm sandy sediment with a $50 \mathrm{~mL}$ BD Falcon tube (BD Biosciences, San Jose, CA, USA) at two or three places in an area of about $1 \mathrm{~m}^{2}$. After a dilution with an equal volume of seawater, the samples were fixed either with acidic Lugol's solution for samples collected in 2007 , or with $4 \%$ neutral formaldehyde for samples collected before.

\section{Light and scanning electron microscopy}


Individual cells were isolated from field samples and washed in distilled water using a micropipette under an Olympus IX51 (Olympus, Tokyo, Japan) inverted microscope. Cells were transferred between a glass slide and a coverslip, and then examined in light microscopy (LM) with a Olympus BX51 upright microscope equipped with Nomarski Differential Interference Contrast (DIC) optics and a digital camera.

For scanning electron microscopy (SEM), cells were individually isolated and concentrated in $0.2 \mathrm{~mL}$ tubes containing distilled water and a drop of formaldehyde to prevent fungal development. Cells were filtered using polycarbonate membrane filters (Millipore, Billerica, MA, USA, GTTP Isopore, $0.22 \mu \mathrm{m}$ pore size), rinsed in deionized water and prepared according to Chomérat and Couté (2008). The examination of dinoflagellate cells was performed with a Quanta 200 (FEI, Eindhoven, The Netherlands) scanning electron microscope. In LM, cells were measured using a calibrated micrometer on the eyepiece, while SEM digital micrographs were processed with ImageJ software (Rasband 1997-2006). SEM photographs were presented on a dark gray background using Adobe Photoshop CS2, v. 9.0.2 (Adobe Systems, San Jose, CA, USA).

\section{DNA amplification and sequencing}

After their identification, single cells of $P$. consutum were isolated from Groix Island field samples of 2007 using a micropipette under the IX51 inverted microscope and transferred onto a glass slide. Each cell was rinsed individually in several drops (three to six) of double distilled water and then transferred to $0.2 \mathrm{~mL}$ PCR tube containing $5 \mu \mathrm{L}$ of $\mathrm{ddH}_{2} \mathrm{O}$. Then, PCR tubes were stored at $-20^{\circ} \mathrm{C}$. For PCR, the samples were thawed and $25 \mathrm{pmol}$ of each primer and 12.5 $\mu \mathrm{L}$ of PCR Master Mix 1X (Promega, Madison, 
WI, USA) containing the Taq DNA polymerase, $\mathrm{dNTPs}, \mathrm{MgCl}_{2}$ and reaction buffers, were added in each tube.

Almost the full length of the SSU rDNA (approximately 1800 base pairs) was specifically amplified using primers $18 \mathrm{~S}-\mathrm{FW}$ and $18 \mathrm{~S}-\mathrm{RV}$ (Table 1). For the LSU rDNA, primers 28S-D1R (Scholin and Anderson 1994) and 28S-1483R (Daugbjerg et al. 2000) were used to amplify expected fragment of approximately $1500 \mathrm{bp}$. PCR products were diluted in $\mathrm{ddH}_{2} \mathrm{O}(1 / 100)$ and $1 \mu \mathrm{L}$ of the dilution was used as a DNA template for the second round of PCR. Several pairs of internal primers (Table 1) were used to acquire the complete sequences. The polymerase chain reactions for both rounds were performed in a Mastercycler Personal (Eppendorf, Hamburg, Germany) as follows: one initial denaturating step at $94^{\circ} \mathrm{C}$ for $2 \mathrm{~min}$, followed by 45 cycles each consisting of $94^{\circ} \mathrm{C}$ for $30 \mathrm{sec}, 54^{\circ} \mathrm{C}$ for $30 \mathrm{sec}$, and $72^{\circ} \mathrm{C}$ for $4 \mathrm{~min}$, and a final elongation of $72^{\circ} \mathrm{C}$ for $5 \mathrm{~min}$.

The PCR products were purified using the Wizard SV Gel and PCR Clean-up system (Promega) according to the manufacturer's recommendations. Then, they were sequenced directly using the ABI PRISM BigDye Terminator Cycle Sequencing Kit (Applied Biosystems, Carlsbad, CA, USA). Sequencing products were purified by exclusion chromatography using the Dye Terminator Removal Kit (Abgene Ltd., Epsom, United Kingdom) and the sequences were determined using an automated 3130 genetic analyser (Applied Biosystems).

\section{Sequences alignment and phylogenetic analyses}

The SSU and LSU rDNA sequences obtained were aligned with other putative Prorocentrum species and two outgroup (Scrippsiella spp.) sequences using Clustal W 
(Thompson et al. 1994) followed by refinement by eye with BioEdit version 7.0.0 (Hall 1999). Genbank accession numbers of all sequences used are available in the supplementary material (Appendix S1).

Evolutionary models were examined for each data set using maximum likelihood (ML), Bayesian inference analysis (BI) and maximum parsimony (MP). The evolutionary model and parameters were selected after running ModelGenerator version 0.82 (Keane et al. 2006). For both datasets, ModelGenerator indicated the need for a general time reversible (GTR) model with a gamma correction $(\Gamma)$ for among-site rate variation and invariant sites (except for LSU rDNA) according to hierarchical likelihood ratio tests (hLRT), the Akaike Information Criterions (AIC1 and AIC2) and the Bayesian Information Criterion (BIC).

Maximum likelihood analyses were performed using PhyML version 2.4.4 (Guindon and Gascuel 2003), Bayesian analyses were run using Mr Bayes version 3.1.2 (Ronquist and Huelsenbeck 2003) and parsimony analyses with heuristic search were performed using PAUP* version 4 Beta for Windows (Swofford 2002).

Bootstrap analysis (1000 replicates) was used (for ML and MP) to assess the relative robustness of branches (bootstrap values, bv) (Felsenstein 1985).

Initial Bayesian analyses were run with a GTR model (nst=6) with rates set to invgamma and nucleotide frequencies set to equal. Each analysis was performed using four Markov chains (MCMC), with two millions cycles for each chain. Trees were saved to a file every 100 cycles and the first 2000 trees were discarded. Therefore, a majority-rule consensus tree was created from the remaining 18000 trees in order to examine the posterior probabilities (pp) of each clade. 
The consensus trees were edited using TreeView version 1.6.6 (Page 1996). Two species of Scrippsiella were used to root the trees. The bests ML phylograms are showed with their robustness values for each node (ML, bv / BI, pp / MP, bv).

Results

Observations

Class Dinophyceae Pascher

Order Prorocentrales Lemmermann

Family Prorocentraceae Stein

Genus Prorocentrum Ehrenberg

Prorocentrum consutum Chomérat et Nézan sp. nov.

(Figs. 1-4)

Descriptio:

Organismus photosyntheticus, circularis vel subcircularis in frontali aspectu, compressissimus in apicali aspectu. Longitudo : 57-61 $\mu \mathrm{m}$; latitudo : 52-56 $\mu \mathrm{m}$.

Nucleus nephropsis in posteriori parte. Pyrenoides centralis. Valvae laeves, cum 90-107 areolis circumdatae ; areolae diameter : $0.8-1 \mu \mathrm{m}$; areola cum tribus poris. Valva recta. profunde indentata in apice; valva sinsitra cum apicali crista. Regio periflagellaris cum novem parvis lamellis constituta et cum duobus poris ; aliquae parvae lamellae utraequae ex parte tectae. Porus flagellaris cum tenui crista circumdatus. Valvae cum parvis poris dispersis sed absentibus in centrali parte. Intercalaris regio tenuis laevisque valde leviter transversus striata.

Habitatio: marina et arenicola (marine and sand-dwelling) 
Holotype: Fig. 3A, SEM stub \# 08-E4, deposited at the Marine Biological Station of the National Museum of Natural History, Concarneau.

Isotypes : Figs. 3, B-D.

Type locality: $P$. consutum was first collected from sandy sediments off Moutons Island

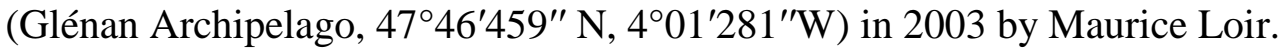

Known distribution: P. consutum was found at several locations around the Moutons Island (Glénan Archipelago) and the Groix Island.

Etymology: From Latin, consutum, stitched, referring to the marginal areolae that appear like a seam at the periphery of valves.

Cells of $P$. consutum are 57.5-60.7 $\mu \mathrm{m}$ long (mean $58.8 \pm 1.0 \mu \mathrm{m}, \mathrm{n}=10)$ and 52.6-55.2 $\mu \mathrm{m}$ wide (mean $54.3 \pm 0.8 \mu \mathrm{m}, \mathrm{n}=10$ ) in valve view and are plainly flattened (Fig. 3, C-D). Cell shape is roughly subcircular to broadly ovoid in valve view (Figs. 1, $\mathrm{A}$ and $\mathrm{C}, 2,3, \mathrm{~A}-\mathrm{B}$ ) and the length to width ratio varies from 1.06 to 1.12 (mean $1.08 \pm$ 0.02, $\mathrm{n}=10$ ). At the anterior end, the cell is slightly narrower (Fig. 1A, 2, 3, A-B). The valves appear to be flat or slightly concave (Fig. 3, C-D).

The valve surface is smooth and a ring of 90 to 107 (mean $95 \pm 5.6, \mathrm{n}=9$ ) large areolae (diameter $0.8-1.0 \mu \mathrm{m}$ ) runs alongside the periphery of valves (Fig. 1, A and C, 2, 3, A-G and I, 4). At lower magnifications, these marginal areolae appear like stitches of a seam (Figs. 1, A and C, 3, A-D) so this distinctive character is used to name the species. On the right valve the areolae interrupt towards the pointed end of the "V"shaped excavation (Figs. 1A, 3, A and E). In contrast, on the left valve, the areolae are continuous and form a large concave "U" shape towards the apical area (Figs. 1C, 3, B and F). These areolae are deep round to oval depressions bearing 3-4 pores on their bottom surface (Fig. 3G). Next to these areolae, some irregular and small shallow 
depressions, devoid of pores at their bottom, run alongside the periphery of valves (Figs. 3, G and I). Small round pores (diameter 0.13-0.17 $\mu \mathrm{m}$ ) located in faint circular depressions are scattered on the valves surface (Fig. $3 \mathrm{H}$ ) but the center of both valves is devoid of pores (Figs. 1, A and C, 3, A-B). The intercalary band of $P$. consutum sp. nov. is generally narrow and faintly striated horizontally (Fig. 3I).

The periflagellar area of $P$. consutum sp. nov. is triangular, located in a deep (ca. $10 \mu \mathrm{m}$ long) excavation of the right valve and is inclined at a sharp angle to the plane of the sagittal suture of the valves (Figs. 1A, 3, A and E, 4). A thick flange (tf) formed by the right valve borders the right side of the periflagellar area and bends at the pointed end of the V-shape (Figs. 3E, 4). The left valve margin exhibits a prominent apical ridge (ar) that is slightly concave in valve views (Figs. 1, A and C, 3, A-B and E-F). This ridge is smooth and not flat; it is undulated towards the left valve in respect to the plane of the sagittal suture (Figs. 3, B and F, 4, A-C). The periflagellar area is complex and some platelets are difficult to observe since they are partially hidden by other platelets. Figure 4 provide different views of the periflagellar area from the same specimen. Nine periflagellar platelets may be recognized. For comparison, they have been labelled according to Taylor's scheme (Taylor 1980). Four platelets, namely “a ", “d”, “f”, and "h", border the apical ridge formed by the left valve (Figs. 1B, 4, C-D). The three former platelets extend posteriorly and form a fin-like crest structure that partially hides the platelets located underneath, i.e. "b", and "c" (Fig. 4, B-D). Therefore, the exact delimitation and the contacts of these platelets could not be determined from our observations. Platelet " $\mathrm{a}_{2}$ " is the most difficult to observe since it is often hidden by the thick flange (tf) bordering the periflagellar area (Fig. 4, A-C). The flagellar pore (fp) is elongated and surrounded by four platelets, namely "f", "g", "e", and "c" (Figs. 1B, 4, 
B-D). Posterior margins of platelets " $a_{1}$ " and " $d$ ", and those in contact with the flagellar pore form a short collar encircling the pore area (Figs. 3E, 4D). The accessory pore (ap) is partially observed and appears to be surrounded by the platelets "b" and "c" only (Figs. 1B, 4, A-B and D). Some platelets are ornamented with areolae of variable depths. Platelet " $a_{1}$ " that is the largest of the series bears three deep areolae and a faint depression while other platelets have only one areola or depression (Fig. 4).

Prorocentrum consutum sp. nov. is a photosynthetic species containing several chloroplasts and a starch-sheathed pyrenoid that appears as a central ring shape under LM (Fig. 2). A large posterior kidney-shaped nucleus is situated adjacent to the pyrenoid (Fig. 2). No investigation on the potential toxicity of this new species has been carried out in this study.

Phylogenetic position of Prorocentrum consutum as inferred from SSU and LSU rDNA sequences

For SSU rDNA, a fragment of 1787 base pairs was obtained using the primer pair 18SFW and 18S-RV. The determined informative sequence between the two primers is 1746 bp long covering the near complete 18S rDNA. For LSU rDNA, a fragment of 1506 bp was obtained using the primer pair 28S-D1R and 28S-1483R. The determined informative sequence is 1465 bp long. For both markers, two sequences were determined from two independent cells and the identity between the two sequences is $100 \%$ for SSU as for LSU fragment.

The new phylogenetic relationships of Prorocentrum species were reconstructed based on two different sequence data sets: one included nucleotide sequences of nuclear partial SSU rDNA (1711 characters, 21 taxa), the second was a data set of partial LSU 
rDNA (967 characters, 25 taxa). Concerning molecular data of Prorocentrum consutum sp. nov., 1703 and 908 nucleotides for the SSU rDNA and LSU rDNA were used respectively in the phylogenetic analyses. The new sequences have been deposited in GenBank under accession Nos. FJ842379 for SSU rDNA, FJ842378 for LSU rDNA.

The resulting phylogenetic tree inferred from SSU rDNA indicated the existence of two major lineages within the genus Prorocentrum (Fig. 5). The clades comprised the taxa $P$. panamense, $P$. emarginatum, $P$. tsawwassenense, $P$. micans, $P$. mexicanum, $P$. triestinum, $P$. gracile, $P$. minimum, $P$. donghaiense and $P$. dentatum (Clade 1) and $P$. levis, $P$. concavum, $P$. consutum sp. nov., $P$. belizeanum, $P$. maculosum, $P$. lima and $P$. arenarium (Clade 2) (Fig. 5). Two well supported groups were recognized in Clade 2, the first comprised $P$. levis and $P$. concavum and the second included $P$. consutum, $P$. belizeanum, $P$. maculosum, $P$. lima and $P$. arenarium (Fig. 5). The new species $P$. consutum formed a sister clade to that represented by $P$. belizeanum, $P$. maculosum, $P$. lima and P. arenarium (Fig. 5). This position was supported by a posterior probability of 0.99 in BI but bootstraps values in ML and MP were $84 \%$ and $75 \%$, respectively.

For the LSU rDNA phylogenetic analysis, the tree topology was similar to that found in the phylogeny inferred from SSU rDNA (Fig. 6). Prorocentrum consutum appeared in Clade 2 and formed a sister clade to that represented by $P$. arenarium, $P$. lima, $P$. hoffmannianum and $P$. belizeanum, as found in the SSU analysis. Its position was well supported by high bootstrap and posterior probability values (Fig. 6).

Consistency index (CI) determined by maximum parsimony analyses (MP) was 0.7518 and 0.7527 for SSU and LSU rDNA genes, respectively. Retention index (RI) was 0.8563 and 0.8868 in SSU and LSU rDNA analyses, respectively. These data sets are structured enough and exhibit low levels of homoplasy. 
Discussion

Morphology

Compared with other benthic Prorocentrum species, $P$. consutum has very peculiar characters. It is among the largest benthic Prorocentrum species and is in the same size range than $P$. belizeanum (Table 2). Only two other species, $P$. foraminosum Faust and $P$. reticulatum Faust can reach about $60 \mu \mathrm{m}$ or more in length, but their width is always lesser than $45 \mu \mathrm{m}$ (Faust 1993b, Faust 1997) and are differently shaped.

Among benthic Prorocentrum species, the thecal ornamentation of $P$. consutum sp. nov. is very distinctive (Table 2). All previously known benthic species are either uniformly smooth, e.g. $P$. arenarium, $P$. elegans, $P$. levis, $P$. lima or uniformly areolate, e.g. $P$. belizeanum, $P$. concavum, $P$. hoffmannianum (Table 2), except in $P$. concavum reported without areolae in the center of valves (Faust and Gulledge 2002). However, $P$. maculosum and $P$. faustiae are exceptions, being devoid of areolae but with a rugose surface (Faust 1993b, Morton 1998). Some species are reported with marginal pores on the periphery of valves (Table 2). In contrast, the theca of $P$. consutum sp. nov. is very peculiar, being smooth with a ring of areolae at the periphery of the valves. These areolae are mostly round, deep and with several pores at their bottom, which is distinct from any other known benthic Prorocentrum species. $P$. belizeanum, $P$. concavum, $P$. hoffmannianum and $P$. sabulosum are uniformly areolated and possess round to oval areolae (Faust 1990, Faust 1994) while $P$. ruetzlerianum has pentagonal-shaped areolae (Faust 1994). However, the areolae of $P$. hoffmannianum and $P$. sabulosum are, respectively, $1-1.15 \mu \mathrm{m}$ and $1-1.6 \mu \mathrm{m}$ in diameter (Faust 1993a, Faust 1994), which is larger than those observed in $P$. consutum. In contrast, the areolae of $P$. belizeanum and 
P. concavum are smaller, being respectively $0.66-0.88 \mu \mathrm{m}$ (Faust 1993a) with an average size of $0.8 \mu \mathrm{m}$ (Faust and Gulledge 2002). Contrary to areolate species in which not every areola has a thecal pore, all marginal areolae in $P$. consutum contain several pores. The presence of several pores in an areola is unusual and is yet only reported for P. hoffmannianum where some areolae contain two pores (Faust 1990, Fig. 17). In $P$. maculosum, marginal pores were described as circular depressions with raised edges, pierced by much smaller pores (Faust 1993b).

The overall arrangement of the periflagellar area of $P$. consutum shares some similarities with other species, such as a triangular periflagellar area located in a deep, $\mathrm{V}$-shaped excavation of the right valve and an apical ridge formed by the left valve. Prorocentrum belizeanum, $P$. hoffmannianum, $P$. lima, $P$. maculosum, $P$. sabulosum and $P$. reticulatum possess both of these characters (Faust 1990, Faust 1991, Faust 1993a, Faust 1994, Faust 1997, Faust et al. 2008) whereas $P$. concavum and $P$. foraminosum lack an apical ridge (Faust 1990, Faust 1993b, Mohammad-Noor et al. 2007b). However, owing to the deep excavation of the right valve, the apical ridge of $P$. consutum is very prominent, which is distinct from previously described species. Moreover, this species possesses a narrow collar (or short flange) surrounding the flagellar area as in P. belizeanum, $P$. concavum, $P$. hoffmannianum, $P$. lima, $P$. maculosum, P. sabulosum (Table 2) and P. reticulatum (Faust 1993b, Faust 1994, Faust 1997).

In comparison with the general scheme proposed by Taylor, the periflagellar area of $P$. consutum sp. nov. consisted in nine platelets instead of eight (Taylor 1980). This is consistent with the results of Mohammad-Noor et al. (2007a) who found that $P$. concavum (synonym $P$. arabianum Morton et Faust) possesses also one extra plate " $\mathrm{a}_{2}$ " 
between "a,", "b" and "e". However, the platelets "b" and "c" in P. concavum are not located underneath an extension of " $\mathrm{a}_{1}$ " and "d" as in $P$. consutum (Mohammad-Noor et al. 2007a). Only the use of transmission electron microscopy and serial sectioning would allow to resolve the arrangement of platelets located underneath, as proposed by Zhou and Fritz (1993) and Mohammad-Noor et al. (2007a). However this method requires cultures or a great number of cells and is hardly possible with rare specimens from field samples.

\section{Molecular analyses and phylogeny}

The phylogenies of Prorocentrum species inferred in this study using two different genes were similar and consistent with previous phylogenetic analyses using ribosomal genes that showed that the species fall in two major lineages (Grzebyk et al. 1998, Murray et al. 2007, Faust et al. 2008, Hoppenrath and Leander 2008, Murray et al. 2009). As suggested by Grzebyk et al. (1998) and Faust et al. (2008), the two clades can be distinguished based on the morphology of the valves, in particular, whether the valves display a symmetry around a mid-valve line. Clade 1 of our analyses consists in asymmetric species or those with variable valve morphologies, while Clade 2 comprises symmetric species.

The position of $P$. consutum sp. nov. within Clade 2 including symmetric species, is confirmed by the phylogenies inferred from both SSU and LSU rDNA and is relevant with its morphological features. In the phylogenetic analyses, $P$. consutum is related to the benthic species $P$. arenarium, $P$. concavum, $P$. levis, $P$. lima, $P$. belizeanum and $P$. hoffmannianum, which is consistent with the habitat of this new species. The branch length between $P$. consutum sp. nov. and the other species and its 
peculiar position in both phylogenetic analyses, forming a new sister-clade to the group of $P$. lima, confirmed unequivocally that its sequence is distinct from all other existing sequences and supports the establishment of this new species.

As emphasized by Faust et al. (2008) for SSU gene sequences, our results showed that care should be given to the interpretation of the relationships among species from phylogenetic analyses since some molecular sequences can be doubtfully identified. In our LSU rDNA analysis, two sequences identified as $P$. arenarium were used but their position was surprisingly different in the resulting tree, which indicates either a considerable genetic variability among populations of this species or a possible misidentification of the organism. The sequence of $P$. arenarium isolated from Réunion Island (accession number AJ567456) is located in the clade comprising P. lima, as found for the P. arenarium sequence Y16234 in the SSU rDNA analysis. However, the other sequence from Malaysia (EF566747) grouped in the P. hoffmannianum / belizeanum clade. Since these two sequences diverge from $4.2 \%$, they can hardly belong to the same taxon or it may indicate the possible existence of a cryptic species. In absence of additional genetic sequences and of a detailed morphological study of both populations, it is not possible to conclude. For this reason, it would be important that authors provide detailed pictures of the organisms in complement to the DNA sequences as it is obvious that there are confusions over species identification (Faust et al. 2008). In the same way, it is also important that the molecular data could be established on sequences long enough allowing the construction of reliable phylogenetic trees.

Ribosomal DNA genes have been widely chosen to infer phylogenetic relationships among Prorocentrum species but most studies included a unique genetic 
marker, either SSU rDNA (Grzebyk et al. 1998, H. Zhang et al. 2005, Zhang et al. 2007, Faust et al. 2008, Hoppenrath and Leander 2008) or LSU rDNA (C. Zhang et al. 2005, Mohammad-Noor et al. 2007a, Murray et al. 2007). Consequently, for several species only one ribosomal subunit sequence is known and, thus, they could not be positioned in phylogenies inferred from another marker. Our approach allowed us to include more species in the phylogenetic analyses and confirmed that $P$. consutum has a similar and well supported position in phylogenies inferred from SSU and LSU rDNA genes. Some authors argued that combined analyses of several genes can be superior to single genes analyses because they contain more phylogenetic information, and because certain taxa have a fast evolutionary rate in one gene and not in another, and so the use of both genes may mitigate the detrimental effect of a single divergent sequence (Gontcharov et al. 2004, Murray et al. 2007). Due to the limited number of Prorocentrum species for which both SSU and LSU rDNA genes are sequenced, such an analysis was not possible in our study. Moreover, the use of other genes than those of the ribosomal operon, including mitochondrial genes such as cytochrome oxydase (cox 1 ) or cytochrome $b$ $(c o b)$ genes, could be very useful and more powerful to infer dinoflagellates phylogeny, especially for closely related taxa (H. Zhang et al. 2005, Lin et al. 2006, Zhang et al. 2007, Murray et al. 2009). Nevertheless, sequences of these genes are available only for a few Prorocentrum species, mostly those of Clade 1 while they remain to be acquired for most of species of Clade 2. In a very recent work, Murray et al. (2009) obtained several new sequences and showed that the phylogenies inferred from nuclear ribosomal genes and mitochondrial genes were not congruent and could be difficult to interpret. It is obvious that not a single marker but a combination of several genes including nuclear and mitochondrial genes would better resolve the phylogeny of dinoflagellates. Such 
works are not yet possible for benthic Prorocentrum species and further studies should manage to include several genetic markers to increase the number of available sequences and allow combined analyses.

Contrary to previous phylogenetic studies inferred from the SSU rDNA gene which showed that Prorocentrum is probably polyphyletic (Grzebyk et al. 1998, Saldarriaga et al. 2001, 2003, 2004), a recent three-genes analysis demonstrated the possible monophyly of the genus (Zhang et al. 2007). However, this combined analysis included $P$. lima as the unique species of Clade 2. In the study made by Murray et al. (2009), the phylogeny inferred from cox 1 gene suggested the monophyly of the group while nuclear ribosomal genes did not support this topology or were inconclusive. Thus, the monophyly of Prorocentrales is still in question and needs to be confirmed with the inclusion of several species in a multi-genes combined analysis. In this approach, if symmetric and asymmetric species appear to be located in different clades as in the phylogenies inferred from rDNA genes, the existence of the unique genus Prorocentrum will be in question and the reinstatement of the genus Exuviaella as proposed by McLachlan et al. (1997) for symmetric species could be reconsidered.

In conclusion, both morphological and phylogenetic analyses confirmed unambiguously that $P$. consutum sp. nov. is a new benthic Prorocentrum species. Its large size, shape and unusual valve ornamentation yet never reported in any described species, are good criteria that allow its identification.

\section{Acknowledgements}

The authors wish to thank Dr. Alain Couté for the Latin diagnosis and Philippe Crassous for his assistance during SEM observations. S. Boulben and K. Chèze are 
thanked for the DNA amplifications and sequencing reactions. We thank the two anonymous reviewers for very useful comments and suggestions. This study was partly funded by the Contrat de Projet Etat-Région and is a contribution to the Brittany Culture Collection project. 
References

Abé, T. H. 1967. The armoured Dinoflagellata: II. Prorocentridae and Dinophysidae (A). Publ. Seto Mar. Biol. Lab. 14:369-89.

Balech, E. 1956. Étude des dinoflagellés du sable de Roscoff. Rev. Algol. 2:29-52.

Chomérat, N. \& Couté, A. 2008. Protoperidinium bolmonense sp. nov. (Peridiniales, Dinophyceae), a small dinoflagellate from a brackish hypereutrophic lagoon (South of France). Phycologia 47:392-403.

Chomérat, N. \& Nézan, E. 2009. Cabra reticulata sp. nov. (Dinophyceae), a new sanddwelling dinoflagellate from the Atlantic Ocean. Eur. J. Phycol. 44:in press.

Chomérat, N., Loir, M. \& Nézan, E. 2009. Sinophysis verruculosa sp. nov. (Dinophysiales, Dinophyceae), a new sand-dwelling dinoflagellate from South Brittany, northwestern France. Bot. Mar. 52:69-79.

Daugbjerg, N., Hansen, G., Larsen, J. \& Moestrup, Ø. 2000. Phylogeny of some of the major genera of dinoflagellates based on ultrastructure and partial LSU rDNA sequence data, including the erection of three new genera of unarmoured dinoflagellates. Phycologia 39:302-17.

Dodge, J. D. 1975. The Prorocentrales (Dinophyceae). II. Revision of the taxonomy within the genus Prorocentrum. Bot. J. Linn. Soc. 71:103-25.

Dragesco, J. 1965. Étude cytologique de quelques flagellés mésopsammiques. Cah. Biol. Mar. 6:83-115. 
Faust, M. A. 1990. Morphologic details of six benthic species of Prorocentrum (Pyrrophyta) from a mangrove island, Twin Cays, Belize, including two new species. $J$. Phycol. 26:548-58.

Faust, M. A. 1991. Morphology of ciguatera-causing Prorocentrum lima (Pyrrophyta) from widely differing sites. J. Phycol. 27:642-48.

Faust, M. A. 1993a. Prorocentrum belizeanum, Prorocentrum elegans, and Prorocentrum caribbaeum, three new benthic species (Dinophyceae), from a mangrove island, Twin Cays, Belize. J. Phycol. 29:100-07.

Faust, M. A. 1993b. Three new benthic species of Prorocentrum (Dinophyceae) from twin Cays, Belize: P. maculosum sp. nov., P. foraminosum sp. nov. and P. formosum sp. nov. Phycologia 32:410-18.

Faust, M. A. 1994. Three new benthic species of Prorocentrum (Dinophyceae) from Carrie Bow Cay, Belize: $P$. sabulosum sp. nov., $P$. sculptile sp. nov. and $P$. arenarium sp. nov. J. Phycol. 30:755-63.

Faust, M. A. 1997. Three new benthic species of Prorocentrum (Dinophyceae) from Belize: $P$. norrisianum sp. nov., $P$. tropicalis $\mathrm{sp}$. nov., and $P$. reticulatum sp. nov. $J$. Phycol. 33:851-58.

Faust, M. A. \& Gulledge, R. A. 2002. Identifying harmful marine dinoflagellates. Smithsonian Institution. Contributions from the United States National Herbarium 42:1144. 
Faust, M. A., Vandersea, M. W., Kibler, S. R., Tester, P. A. \& Litaker, R. W. 2008. Prorocentrum levis, a new benthic species (Dinophyceae) from a mangrove island, Twin Cays, Belize. J. Phycol. 44:232-40.

Felsenstein, J. 1985. Confidence limits on phylogenies: An approach using the bootstrap. Evolution 39:783-91.

Fukuyo, Y. 1981. Taxonomical study on benthic dinoflagellates collected in coral reefs. Bull. Jap. Soc. Sci. Fish. 47:967-78.

Gontcharov, A. A., Marin, B. \& Melkonian, M. 2004. Are combined analyses better than single gene phylogenies? A case study using SSU rDNA and $r b c \mathrm{~L}$ sequence comparisons in the Zygnematophyceae (Streptophyta). Mol. Biol. Evol. 21:612-24.

Grzebyk, D., Sako, Y. \& Berland, B. 1998. Phylogenetic analysis of nine species of Prorocentrum (Dinophyceae) inferred from 18S ribosomal DNA sequences, morphological comparisons, and description of Prorocentrum panamensis, sp. nov. J. Phycol. 34:1055-68.

Guindon, S. \& Gascuel, O. 2003. A simple, fast, and accurate algorithm to estimate large phylogenies by maximum likelihood. Syst. Biol. 52:696-704.

Hall, T. A. 1999. BioEdit: a user-friendly biological sequence alignment editor and analysis program for Windows 95/98/NT. Nucleic Acids Symp. Ser. 41:95-98.

Hoppenrath, M. 2000a. A new marine sand-dwelling Prorocentrum species, P. clipeus sp. nov. (Dinophyceae, Prorocentrales) from Helgoland, German Bight, North Sea. Eur. J. Protistol. 36:29-33. 
Hoppenrath, M. 2000b. Taxonomische und oekologische Untersuchungen von Flagellaten mariner Sande. Ph.D. dissertation. University of Hamburg, Hamburg, 311 pp.

Hoppenrath, M. \& Leander, B. S. 2008. Morphology and molecular phylogeny of a new marine sand-dwelling Prorocentrum species, P. tsawwassenense (Dinophyceae, Prorocentrales), from British Columbia, Canada. J. Phycol. 44:451-66.

Keane, T. M., Creevey, C. J., Pentony, M. M., Naughton, T. J. \& McInerney, J. O. 2006. Assessment of methods for amino acid matrix selection and their use on empirical data shows that ad hoc assumptions for choice of matrix are not justified. BMC Evol. Biol. 6: 29.

Larsen, J. 1985. Algal studies of the Danish Wadden Sea II. A taxonomic study of psammobious dinoflagellates. Opera Bot. 79:14-37.

Lin, S., Zhang, H. \& Jiao, N. 2006. Potential utility of mitochondrial cytochrome $b$ and its mRNA editing in resolving closely related dinoflagellates: a case study of Prorocentrum (Dinophyceae). J. Phycol. 42:646-54.

Loeblich, A. R., III 1970. The amphiesma or dinoflagellate cell covering. In: Yochelson, E. L. [Ed.] Proceedings of the North American Paleontological Convention. Allen Press, Lawrence, KS, pp. 867-929.

McLachlan, J.-L., Boalch, G. T. \& Jahn, R. 1997. Reinstatement of the genus Exuviaella (Dinophyceae, Prorocentrophycidae) and an assessment of Prorocentrum lima. Phycologia 36:38-46. 
Mohammad-Noor, N., Moestrup, Ø. \& Daugbjerg, N. 2007a. Light, electron microscopy and DNA sequences of the dinoflagellate Prorocentrum concavum (syn. $P$. arabianum) with special emphasis on the periflagellar area. Phycologia 46:549-64.

Mohammad-Noor, N., Daugbjerg, N., Moestrup, Ø. \& Anton, A. 2007b. Marine epibenthic dinoflagellates from Malaysia - a study of live cultures and preserved samples based on light and scanning electron microscopy. Nord. J. Bot. 24:629-90.

Morton, S. L. 1998. Morphology and toxicology of Prorocentrum faustiae sp. nov., a toxic species of non-planktonic dinoflagellate from Heron Island (Australia). Bot. Mar. 41:565-69.

Murray, S., Nagahama, Y. \& Fukuyo, Y. 2007. Phylogenetic study of benthic, spinebearing prorocentroids, including Prorocentrum fukuyoi sp. nov. Phycol. Res. 55:91102.

Murray, S., Ip, C. L. C., Moore, R., Nagahama, Y. \& Fukuyo, Y. 2009. Are prorocentroid dinoflagellates monophyletic? A study of 25 species based on nuclear and mitochondrial genes. Protist 160:245-64.

Page, R. D. M. 1996. TREEVIEW: An application to display phylogenetic trees on personal computers. Comput. Appl. Biosci.12:357-58.

Rasband, W. S. 1997-2006. ImageJ. 1.37c. National Institutes of Health. Bethesda, Maryland.

Ronquist, F. \& Huelsenbeck, J. P. 2003. MrBayes 3: Bayesian phylogenetic inference under mixed models. Bioinformatics 19:1572-74. 
Saldarriaga, J. F., Taylor, F. J. R., Keeling, P. J. \& Cavalier-Smith, T. 2001.

Dinoflagellate nuclear SSU rRNA phylogeny suggests multiple plastid losses and replacements. J. Mol. Evol. 53:204-13.

Saldarriaga, J. F., Leander, B. S., Taylor, F. J. R. \& Keeling, P. J. 2003. Lessardia elongata gen. et sp. nov. (Dinoflagellata, Peridiniales, Podolampaceae) and the taxonomic position of the genus Roscoffia. J. Phycol. 39:368-78.

Saldarriaga, J. F., Taylor, F. J. R., Cavalier-Smith, T., Menden-Deuer, S. \& Keeling, P. J. 2004. Molecular data and the evolutionary history of dinoflagellates. Eur. J. Protistol. 40:85-111.

Scholin, C. \& Anderson, D. M. 1994. Identification of group- and strain-specific genetic markers for globally distributed Alexandrium (Dinophyceae). I. RFLP Analysis of SSU rRNA genes. J. Phycol. 30:744-54.

Swofford, D. L. 2002. PAUP* beta version. Phylogenetic analysis using parsimony (*and other methods). v. 4b4-10. Sinauer Associated. Sunderland, MA.

Taylor, F. J. R. 1980. On dinoflagellate evolution. Biosystems 13:65-108.

Thompson, J. D., Higgins, D. G. \& Gibson, R. A. 1994. CLUSTAL W: improving the sensitivity of progressive multiple sequence alignment through sequence weighting, position-specific gap penalties and weight matrix choice. Nucleic Acids. Res. 22:467380. 
Zhang, C., Han, X., Zou, J., Yu, Z., Song, X. \& Schuett, C. 2005. Molecular identification of Prorocentrum (Dinophyceae) species. Chin. J. Oceanol. Limnol. 23:317-22.

Zhang, H., Bhattacharya, D. \& Lin, S. 2005. Phylogeny of dinoflagellates based on mitochondrial cytochrome $b$ and nuclear small subunit rDNA sequence comparisons. $J$. Phycol. 41:411-20.

Zhang, H., Bhattacharya, D. \& Lin, S. 2007. A three-gene dinoflagellate phylogeny suggests monophyly of Prorocentrales and a basal position for Amphidinium and Heterocapsa. J. Mol. Evol. 65:463-74.

Zhou, J. \& Fritz, L. 1993. Ultrastructure of two toxic marine dinoflagellates, Prorocentrum lima and Prorocentrum maculosum. Phycologia 32:444-50. 
Table 1:

Table 1. Oligonucleotide primers used for amplification and sequencing

\begin{tabular}{|c|c|c|c|c|}
\hline Code & $\begin{array}{l}\text { rDNA } \\
\text { gene }\end{array}$ & $\begin{array}{l}\text { Synthesis } \\
\text { direction }\end{array}$ & Sequence $\left(5^{\prime} \rightarrow 3^{\prime}\right)$ & $\begin{array}{l}\text { Anneals } \\
\text { to }^{\mathrm{a}}\end{array}$ \\
\hline $18 \mathrm{~S}-\mathrm{FW}$ & SSU & Forward & TCCTGCCAGTAGTCATATGC & $1-20$ \\
\hline $18 S-410$ & SSU & Forward & GCGCAAATTACCCAATCCTGA & $421-441$ \\
\hline 18S-R4 & SSU & Forward & AGGGCAAGTCTGGTGCCAG & $537-555$ \\
\hline 18S-R7 & SSU & Reverse & TGGAGCTGGAATTACCGCGGCT & $557-578$ \\
\hline $18 \mathrm{~S}-960$ & SSU & Forward & CATTGATCAAGAACGAAAGTT & $951-971$ \\
\hline Fragi-18SR & SSU & Reverse & GTTTCAGCCTTGCGACCATAC & $\begin{array}{l}1103- \\
1123\end{array}$ \\
\hline $18 \mathrm{~S}-1270$ & SSU & Forward & CGTTCTTAGTTGGTGGAGTGA & $\begin{array}{l}1269- \\
1289\end{array}$ \\
\hline 18S-RV & SSU & Reverse & TGATCCTTCGGCAGGTTCAC & $\begin{array}{l}1768- \\
1787\end{array}$ \\
\hline $\begin{array}{l}\text { 28S- } \\
\text { D1R }\end{array}$ & LSU & Forward & ACCCGCTGAATTTAAGCATA & $1-20$ \\
\hline $\begin{array}{l}\text { 28S- } \\
\text { R520 }\end{array}$ & LSU & Reverse & CGCAAGTTGGCGTTGACGAGCA & $512-533$ \\
\hline $\begin{array}{l}28 \mathrm{~S}- \\
\mathrm{D} 3 \mathrm{~A}\end{array}$ & LSU & Forward & GACCCGTCTTGAAACACGGA & $706-725$ \\
\hline $\begin{array}{l}28 \mathrm{~S}- \\
\mathrm{D} 2 \mathrm{C}\end{array}$ & LSU & Reverse & CCTTGGTCCGTGTTTCAAGA & $711-731$ \\
\hline $\begin{array}{l}28 \mathrm{~S}- \\
1010\end{array}$ & LSU & Forward & AATCGAACCATCTAGTAGCTGG & $979-1000$ \\
\hline 28S-R2 & LSU & Reverse & ATTCGGCAGGTGAGTTGTTAC & $\begin{array}{l}1323- \\
1343\end{array}$ \\
\hline $\begin{array}{l}28 \mathrm{~S}- \\
1483 \mathrm{R}\end{array}$ & LSU & Reverse & GCTACTACCACCAAGATCTGC & $\begin{array}{l}1486- \\
1506\end{array}$ \\
\hline
\end{tabular}


Table 2 : Comparison of morphological features of symmetric and benthic Prorocentrum species related to P. consutum sp. nov.

\begin{tabular}{|c|c|c|c|c|c|}
\hline & $\begin{array}{l}\text { P. consutum sp. } \\
\text { nov. }\end{array}$ & ${ }_{\mathrm{e}}^{P .}$ arenarium Faust $^{\mathrm{b}, \mathrm{c}, \mathrm{d},}$ & $\begin{array}{l}\text { P. belizeanum } \\
\text { Faust }^{\mathrm{c}, \mathrm{f}, \mathrm{g}}\end{array}$ & $\begin{array}{l}\text { P. concavum } \\
\text { Fukuyo }{ }^{\mathrm{c}, \mathrm{e}, \mathrm{h}, \mathrm{i}}\end{array}$ & $\begin{array}{l}\text { P. faustiae Morton } \\
\text { et Faust }\end{array}$ \\
\hline Cell shape & $\begin{array}{l}\text { Subcircular to } \\
\text { broadly ovoid }\end{array}$ & Round to slight oval & Round to slight oval & $\begin{array}{l}\text { Broadly ovate, } \\
\text { pyriform }\end{array}$ & Ovate to roundate \\
\hline Cell size $[\mu \mathrm{m}]$ & L: $57-61, \mathrm{~W}: 52-55$ & $\begin{array}{l}\text { L: } 30-32, \text { W: } 30-32^{b, c} \\
\text { D: } 36-42^{\mathrm{d}} \\
\text { D: } 42-45^{\mathrm{e}}\end{array}$ & L: $55-60, \mathrm{~W}: 50-55$ & $\begin{array}{l}\mathrm{L}: 44-45, \mathrm{~W}: 40^{\mathrm{h}} \\
\mathrm{L}: 50-55, \mathrm{~W}: 38-45^{\mathrm{c}} \text {, }\end{array}$ & $\begin{array}{l}\text { L: 43-49, W: 38- } \\
42\end{array}$ \\
\hline Theca ornamentation & $\begin{array}{l}\text { Smooth with a ring } \\
\text { of marginal areolae }\end{array}$ & Smooth & Areolate & $\begin{array}{l}\mathrm{L}: 43-53, \mathrm{~W}: 38-48^{\mathrm{e}} \\
\text { Areolate (centre of } \\
\text { valves devoid of } \\
\text { ornamentation) }\end{array}$ & $\begin{array}{l}\text { Rugose, not } \\
\text { areolate }\end{array}$ \\
\hline Pyrenoid & Yes, central & Yes, central $\dagger$ & Yes, central & 2 central pyrenoids & Yes, central \\
\hline Nucleus & $\begin{array}{l}\text { Kidney-shaped, } \\
\text { posterior }\end{array}$ & $\begin{array}{l}\text { Kidney-shaped, } \\
\text { Posterior } \dagger\end{array}$ & $\begin{array}{l}\text { Kidney-shaped, } \\
\text { posterior }\end{array}$ & Round, posterior $\dagger$ & $\begin{array}{l}\text { Kidney-shaped, } \\
\text { posterior }\end{array}$ \\
\hline \multicolumn{6}{|l|}{ Periflagellar area } \\
\hline Ridge on left valve & Present & Absent & Present & Absent & Absent \\
\hline No. platelets & 9 & $?$ & $<8 \dagger$ & 8 or 9 & $16(?)$ \\
\hline Narrow collar & Present & Absent & Present & Present & Absent \\
\hline \multicolumn{6}{|l|}{ Pores } \\
\hline Marginal pores & $\begin{array}{l}3-4 \text { pores in each } \\
\text { marginal areola }\end{array}$ & Yes (poroids) & Yes $†$ & No & Yes \\
\hline Valve centre & Devoid & Devoid & Devoid & Devoid & Present \\
\hline Pores size $[\mu \mathrm{m}]$ & $0.13-0.17$ & L: $0.3-0.7, W: 0.1-0.4$ & ND & $\begin{array}{l}0.8^{\mathrm{c}, \mathrm{i}} \\
0.12-0.23^{\mathrm{e}}\end{array}$ & 0.1 \\
\hline Intercalary band & $\begin{array}{l}\text { Faintly horizontally } \\
\text { striated }\end{array}$ & Smooth & $\begin{array}{l}\text { Horizontally } \\
\text { striated }\end{array}$ & $\begin{array}{l}\text { Granulated and } \\
\text { horizontally striated }\end{array}$ & $\begin{array}{l}\text { Transversally } \\
\text { striated }\end{array}$ \\
\hline
\end{tabular}




\begin{tabular}{|c|c|c|c|c|c|}
\hline & $\begin{array}{l}\text { P. hoffmannianum } \\
\text { Faust }^{\mathrm{c}, \mathrm{i}}\end{array}$ & P. levis Faust et al. ${ }^{\mathrm{g}}$ & $\begin{array}{l}\text { P. lima }(\text { Ehrenberg }) \\
\text { Dodge }^{\mathrm{c}, \mathrm{d}, \mathrm{e}, \mathrm{k}}\end{array}$ & $\begin{array}{l}\text { P. maculosum } \\
\text { Faust }^{\mathrm{c}, 1}\end{array}$ & P. sabulosum Faust $^{\mathrm{b}}$ \\
\hline Cell size $[\mu \mathrm{m}]$ & L: 45-55, W: 40-45 & L: $40-44, W: 37-40$ & $\begin{array}{l}\text { L: } 31-47, W: 22-40^{\mathrm{c}, \mathrm{k}} \\
\text { L: } 41-43 ; \mathrm{W}: 31-32^{\mathrm{d}} \\
\mathrm{L}: 38-45, \mathrm{~W}: 27-38^{\mathrm{e}}\end{array}$ & L: $40-50, \mathrm{~W}: 30-40$ & $\mathrm{~L}: 48-50, \mathrm{~W}: 41-48$ \\
\hline Theca ornamentation & Areolate & Smooth & Smooth & Rugose & Areolate \\
\hline Pyrenoid & Yes & Yes, central & Yes & Yes, central & Not observed \\
\hline Ridge on left valve & Present & Absent & Absent & Present $\dagger$ & Present \\
\hline No. platelets & 8 & $7 \dagger(?)$ & 8 & 8 & $<8 \dagger$ \\
\hline Narrow collar & Present & Absent & Present & Present & Present \\
\hline \multicolumn{6}{|l|}{ Pores } \\
\hline Marginal pores & No & $\begin{array}{l}\text { Lines of unevenly } \\
\text { distributed pores }\end{array}$ & Yes & Yes (poroids) & No \\
\hline
\end{tabular}

$\mathrm{L}=$ length $\mathrm{W}=$ width $\mathrm{D}=$ diameter; $\mathrm{ND}=$ no data available; $\dagger=$ not mentioned in the text, inferred from figures; (?) = needs to be confirmed.

References : a this study, ${ }^{\mathrm{b}}$ Faust (1994), ${ }^{\mathrm{c}}$ Faust and Gulledge (2002), ${ }^{\mathrm{d}}$ Grzebyk et al. (1998), ${ }^{\mathrm{e}}$ Mohammad-Noor et al. (2007b), ${ }^{\mathrm{f}}$ Faust (1993a), ${ }^{\mathrm{g}}$ Faust et al. (2008), ${ }^{\mathrm{h}}$ Fukuyo (1981), ${ }^{\mathrm{i}}$ Faust (1990), ${ }^{\mathrm{j}}$ Morton (1998), ${ }^{\mathrm{k}}$ Faust (1991), ${ }^{1}$ Faust (1993b). 
Legends to figures

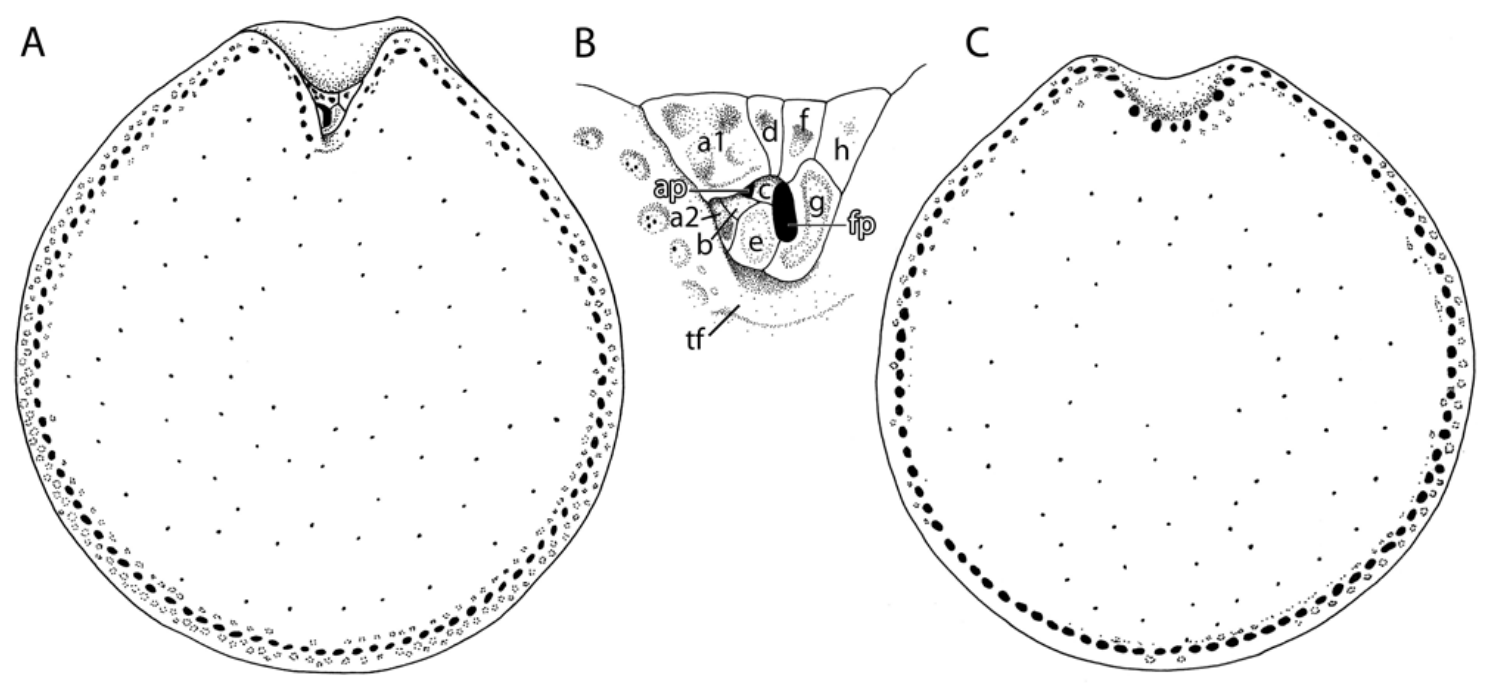

FIG. 1. Line drawings of Prorocentrum consutum sp. nov. (A) Right valve view showing the subcircular shape, deep apical excavation of the periflagellar area and the ring of marginal areolae. (B) Detail of the periflagellar area consisting in nine platelets (a1, a2, b, c, d, e , f, g, h) and two pores (fp, flagellar pore; ap, auxiliary pore). Note the presence of a thick flange (tf) bordering the area. (C) Left valve view. Scale bars, $10 \mu \mathrm{m}$ in $(\mathrm{A}, \mathrm{C})$ and $2 \mu \mathrm{m}$ in $(\mathrm{B})$. 


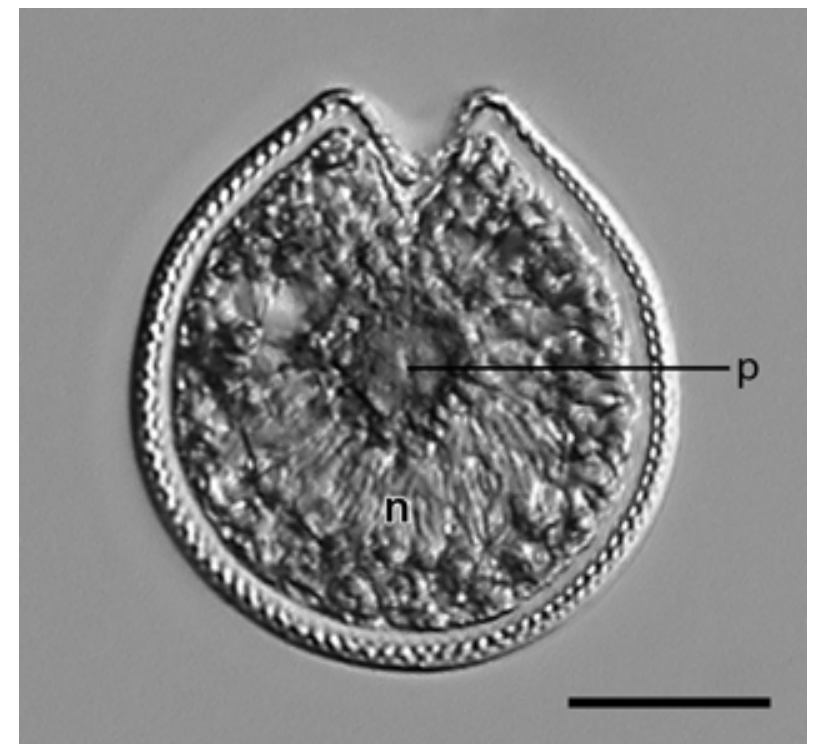

FIG. 2. Light micrographs of Prorocentrum consutum sp. nov. from field sample fixed in Lugol's solution showing the central pyrenoid (p) and the kidney-shaped posterior nucleus (n). Note that marginal areolae appear like a stitch at the periphery of the valve. Scale bar, $20 \mu \mathrm{m}$. 


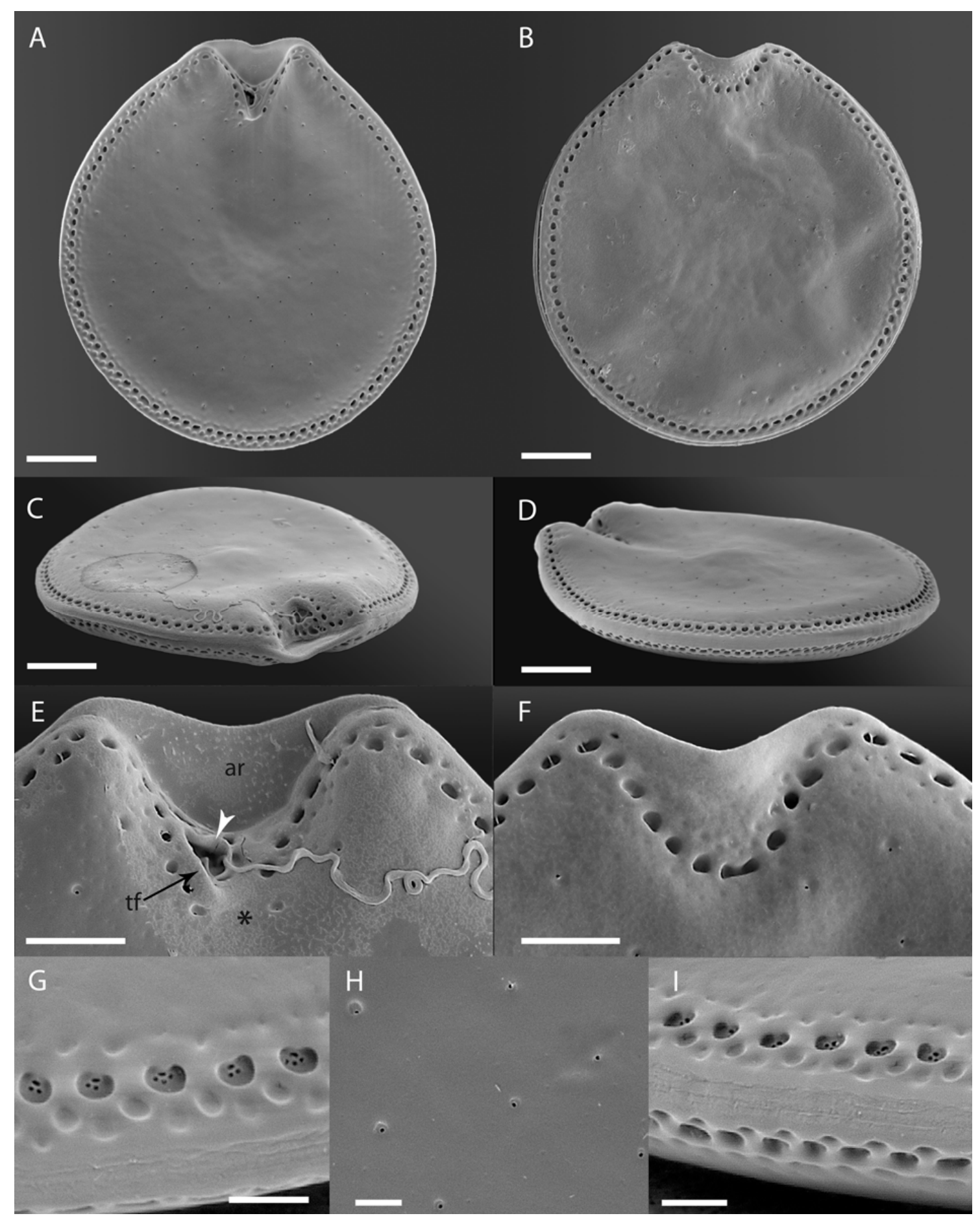

FIG. 3. Scanning electron micrographs of Prorocentrum consutum sp. nov. (stub \#08-

E4), showing general cell surface features. (A) Right valve view showing the deep

excavation of the periflagellar area, the marginal areolae and the pattern of pores. (B)

Left valve view showing the apical ridge, the marginal areolae and the pattern of pores.

(C) Anterior view showing the periflagellar area and the flatness of the cell. (D) 
Posterior view showing the flatness of the cell and the shape of the right valve. (E) Right valve view of the periflagellar area showing the deep excavation and the prominent apical ridge formed by the left valve (ar), the pattern of marginal areolae (the asterisk indicates the incomplete end of the "V"), the thick flange (tf) that borders the right side of the area, and the short collar surrounding the flagellar pore (arrowhead) from which a flagellum emerges. (F) Left valve view of the apical ridge showing its undulation toward the left valve. (G) High magnification view of the valve border showing the marginal areolae formed by circular depressions containing 3-4 pores. $(\mathrm{H})$ High magnification of the valve surface showing the pores. (I) High magnification view showing the faint horizontal striations on the intercalary bands. Scale bars, $10 \mu \mathrm{m}$ in (A-D), $5 \mu \mathrm{m}$ in $(\mathrm{E}, \mathrm{F})$ and $2 \mu \mathrm{m}$ in $(\mathrm{G}-\mathrm{I})$. 


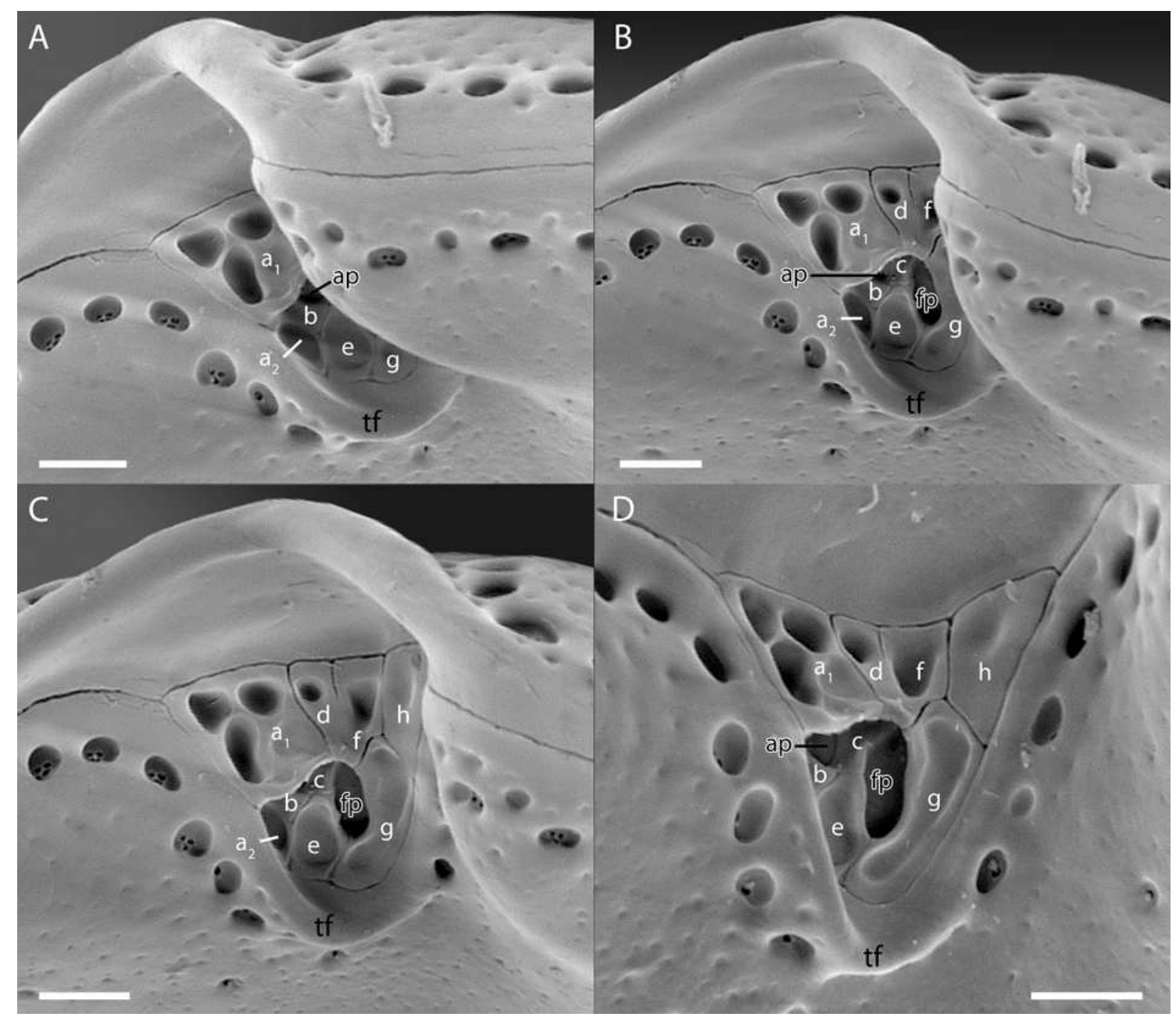

FIG. 4. Scanning electron micrographs of Prorocentrum consutum sp. nov. (stub \#08E4) showing the periflagellar area. (A). Oblique view showing the right side of the area, bordered by a thick flange (tf). (B) View showing the right part of the periflagellar area and the two pores (ap, fp). (C) View showing the nine platelets of the periflagellar area and the flagellar pore (fp). High magnification of the left part of the periflagellar area showing the platelets "b" and "c" located underneath "a $a_{1}$ ". Scale bars, $2 \mu \mathrm{m}$. 
A

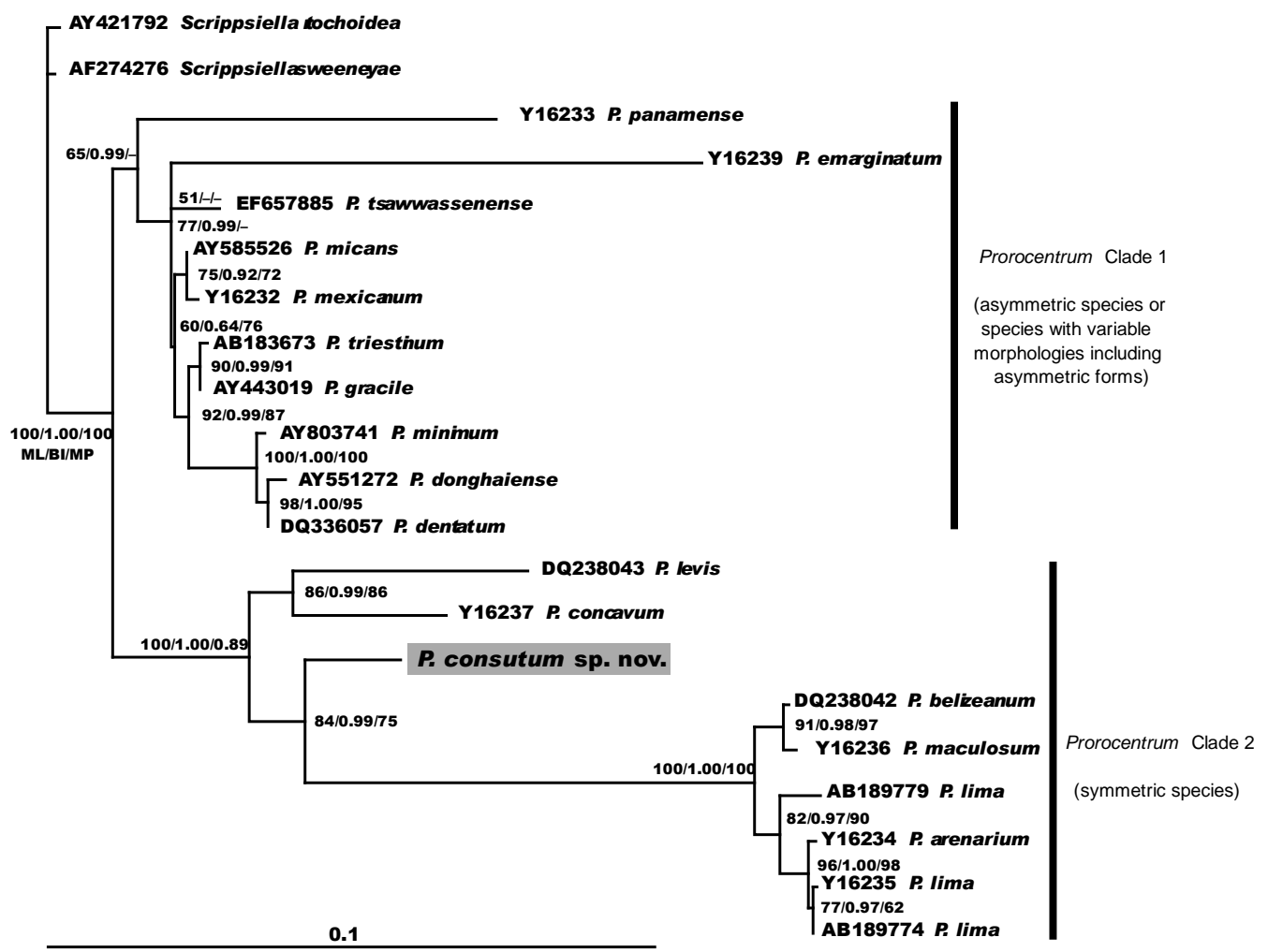

Expectedchanges per site

B

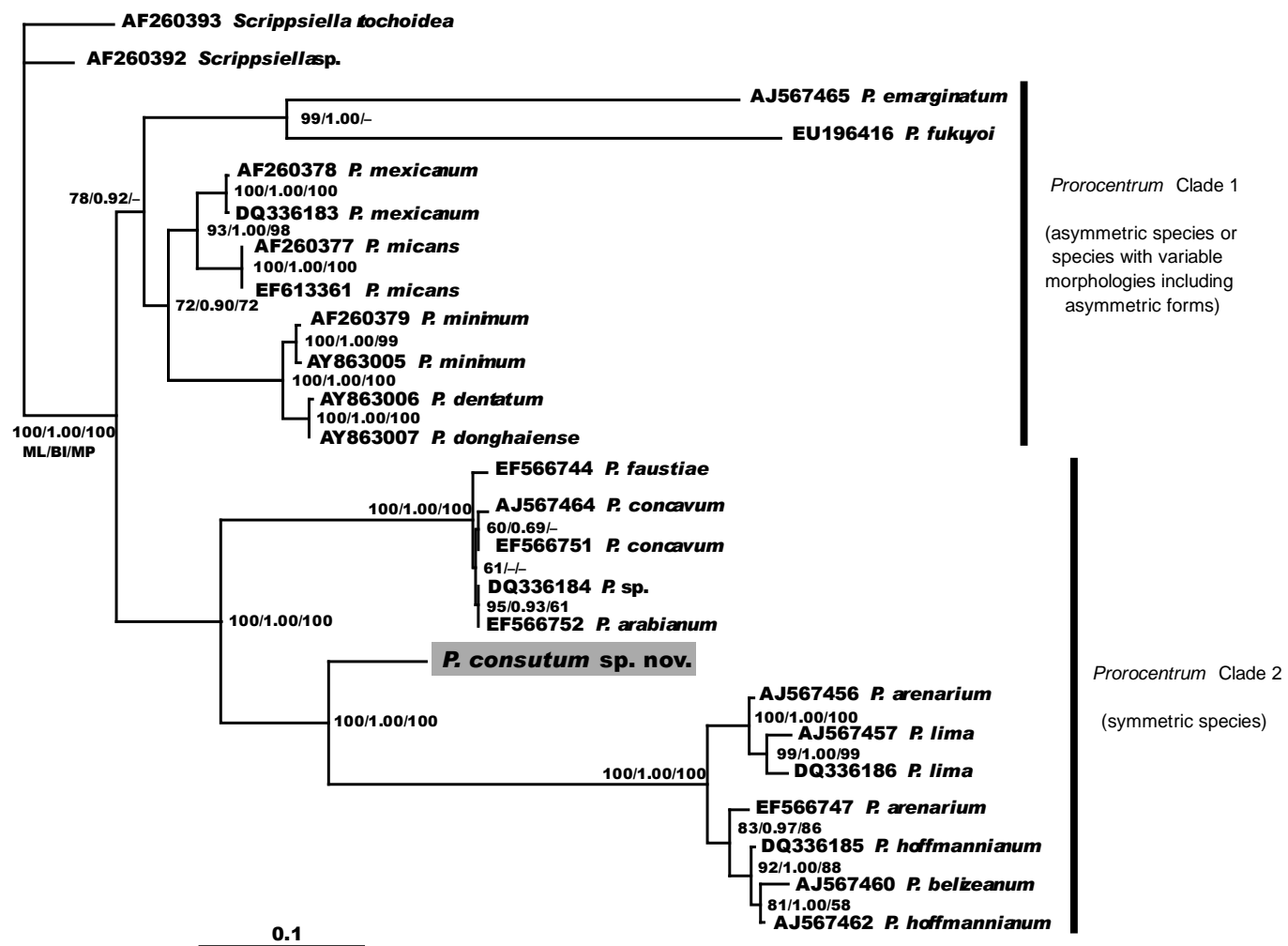

Expectedchanges per site 
FIG 5: Phylogeny of Prorocentrum consutum sp. nov. and other Prorocentrum species.

(A) ML tree inferred from an SSU rDNA data matrix (21 taxa, 1711 characters). The Likelihood value was found to be $\log \mathrm{lk}=-5316.19563$. The tree was rooted using Scrippsiella sequences as outgroup. ML analysis was constrained by user-specified settings obtained from ModelGenerator; model selected: $\mathrm{GTR}+\mathrm{I}+\Gamma_{8}$. Substitution rate matrix: $\mathrm{A} \leftrightarrow \mathrm{C}=1.08891, \mathrm{~A} \leftrightarrow \mathrm{G}=3.50171, \mathrm{~A} \leftrightarrow \mathrm{T}=1.30574, \mathrm{C} \leftrightarrow \mathrm{G}=0.44395, \mathrm{C} \leftrightarrow \mathrm{T}=$ 8.25390, against $\mathrm{G} \leftrightarrow \mathrm{T}$ set to 1.00000 (fixed). Assumed nucleotide frequencies: $\mathrm{f}(\mathrm{A})=$ $0.25393, \mathrm{f}(\mathrm{C})=0.19988, \mathrm{f}(\mathrm{G})=0.26792, \mathrm{f}(\mathrm{T})=0.27827$. Among-site rate variation: assumed proportion of invariable sites: $\mathrm{I}=0.333$ Rates at variable site assumed to be gamma distributed with shape parameter: $\alpha=0.398$. Bootstrap values of ML (1000 replicates), posterior probabilities of $\mathrm{BI}(2,000,000$ generations $)$ and bootstrap values of MP (1000 replicates) are shown at nodes in order from left to right, irresolution noted with “-”. MP method indicated a tree length of 564 steps, consistency index CI $=0.7518$ and retention index $\mathrm{RI}=0.8563(\mathrm{~B}) \mathrm{ML}$ tree inferred from an LSU rDNA data matrix (25 taxa, 967 characters). The Likelihood value was found to be loglk $=-5484.92727$. The tree was rooted using Scrippsiella sequences as outgroup. ML analysis was constrained by user-specified settings obtained from ModelGenerator; model selected: GTR $+\Gamma_{8}$. Substitution rate matrix: $A \leftrightarrow C=0.79870, A \leftrightarrow G=2.25057, A \leftrightarrow T=0.80398$, $\mathrm{C} \leftrightarrow \mathrm{G}=0.66365, \mathrm{C} \leftrightarrow \mathrm{T}=6.03021$, against $\mathrm{G} \leftrightarrow \mathrm{T}$ set to 1.00000 (fixed). Assumed nucleotide frequencies: $f(A)=0.24722, f(C)=0.21019, f(G)=0.30476, f(T)=0.23783$. Rates at variable site assumed to be gamma distributed with shape parameter: $\alpha=$ 0.583. Bootstrap values of ML (1000 replicates), posterior probabilities of BI $(2,000,000$ generations) and bootsrap values of MP (1000 replicates) are shown at nodes 
in order from left to right, irresolution noted with “-”. MP method indicated a tree length of 930 steps, consistency index $\mathrm{CI}=0.7527$ and retention index $\mathrm{RI}=0.8868$. 